NBER WORKING PAPER SERIES

\title{
HOUSEHOLD DEBT OVERHANG DID HARDLY CAUSE A LARGER SPENDING FALL DURING THE FINANCIAL CRISIS IN THE UK
}

\author{
Lars E.O. Svensson \\ Working Paper 28806 \\ http://www.nber.org/papers/w28806 \\ NATIONAL BUREAU OF ECONOMIC RESEARCH \\ 1050 Massachusetts Avenue \\ Cambridge, MA 02138 \\ May 2021
}

I have benefitted from comments from or discussions with Johan Almenberg, Claes Bäckman, Ben Broadbent, Robert Boije, Philip Bunn, Peter Englund, John Muellbauer, Mette Nielsen, May Rostom, and Roine Vestman. I am grateful to the UK Data Service, which has granted me access to the Living Cost and Food Survey and the Wealth and Asset Survey (UK Data Service, 2020). Support from the Jan Wallander and Tom Hedelius research foundation and the Tore Browaldh research foundation is gratefully acknowledged. Views expressed and any errors are my own. The views expressed herein are those of the author and do not necessarily reflect the views of the National Bureau of Economic Research.

NBER working papers are circulated for discussion and comment purposes. They have not been peer-reviewed or been subject to the review by the NBER Board of Directors that accompanies official NBER publications.

(C) 2021 by Lars E.O. Svensson. All rights reserved. Short sections of text, not to exceed two paragraphs, may be quoted without explicit permission provided that full credit, including () notice, is given to the source. 
Household Debt Overhang Did Hardly Cause a Larger Spending Fall during the Financial

Crisis in the UK

Lars E.O. Svensson

NBER Working Paper No. 28806

May 2021

JEL No. E21,G01,G18,G21,R21

\begin{abstract}
The "debt-overhang hypothesis" - that households cut back more on their spending in a crisis when they have higher levels of outstanding mortgage debt (Dynan, 2012) - seems to be taken for granted by macroprudential authorities in several countries in their policy decisions, as well as by the international organizations that evaluate and comment on countries' macroprudential policy. Results are presented for UK microdata that reject the debt-overhang hypothesis. The results instead support the "spending-normalization hypothesis" of Andersen, Duus, and Jensen (2016a), what can also be called the "debt-financed overspending" hypothesis - that the correlation between high pre-crisis household indebtedness and subsequent spending cuts during the crisis reflects high debt-financed spending pre-crisis and a return to normal spending during the crisis. As discussed in Svensson $(2019,2020)$, this is consistent with the correlation reflecting debtfinanced overspending through what Muellbauer (2012) calls the "housing-collateral household demand" and Mian and Sufi (2018) the "credit-driven household demand" channel. The correlation is thus spurious and an example of omitted-variable bias. A simple model shows that consumption and debt changes are directly and strongly positively correlated, whereas consumption and debt levels are quite weakly negatively correlated. Importantly, and in contrast, examples show that there is no systematic relation between consumption cuts and levels of or changes in LTV ratios. The lack of a robust relation between consumption cuts and levels of or changes in LTV ratios implies that tests of these hypotheses should generally not be done by regressions of consumption cuts on levels of or changes in LTV ratios.
\end{abstract}

Lars E.O. Svensson

Department of Economics

Stockholm School of Economics

P.O. Box 6501

SE-11383 Stockholm

Sweden

and NBER

Leosven@gmail.com 


\section{Contents}

1 Introduction $\quad 1$

2 The simplest model of debt-financed overconsumption through the housingcollateral channel

3 The Andersen et al. (2016a) results for Danish microdata 9

4 Results on UK microdata 12

4.1 Bunn and Rostom (2015) . . . . . . . . . . . . . . . . . . . . 12

4.2 Kovacs, Rostom, and Bunn (2018) . . . . . . . . . . . . . 14

5 Conclusion $\quad 15$

$\begin{array}{ll}\text { References } & 17\end{array}$ 


\section{Introduction}

At the micro level, several papers - including Mian and Sufi (2010) and Dynan (2012) for the US, Andersen, Duus, and Jensen (2016a) (ADJ) for Denmark, and Bunn and Rostom (2014, 2015) for the UK - have established a correlation between the level of household indebtedness before the Global Financial Crisis and consumption spending cuts during the crisis. But, as emphasized by ADJ, the mechanism behind this correlation has not been well understood. A common interpretation is indeed that the correlation reflects a negative causal impact of pre-crisis household indebtedness on spending cuts during the crisis, what can be called the "debt-overhang hypothesis" (Dynan, 2012). ADJ calls this interpretation the "household balance-sheet hypothesis." One potential mechanism behind such a causal effect is that households having high levels of debt prior to the crisis were suddenly facing binding borrowing constraints when the crisis broke out and therefore cut spending. Another is that the housing-wealth loss due to falling housing prices and even finding themselves "underwater" induced highly indebted households to delever. A third is that highly levered households cut spending voluntarily due to precautionary motives.

The debt-overhang hypothesis seems to be taken for granted by macroprudential authorities in several countries, as well as by the international organizations that comment on countries' macroprudential policy. Here are two examples, from Finansinspektionen (the Swedish FSA) and the Bank of England: ${ }^{1}$

The risks associated with household debt are primarily related to the possibility that highly indebted households may sharply reduce their consumption in the event of a macroeconomic shock. This development was noted in other countries during the financial crisis in 2008-2009. If many households reduce their consumption at the same time, this can amplify an economic downturn. (Finansinspektionen, 2017, p. 1)

[H]ighly indebted households are more likely to cut their consumption sharply to keep paying their mortgages, deepening the economic downturn. (Carney, 2020, p. 20)

However, ADJ emphasize that the correlation between pre-crisis indebtedness and subsequent spending cuts during the crisis could also reflect that the high debt level among some households was simply the result of high debt-financed spending in previous years, while the subsequent drop in spending reflected a return to normal levels. In this latter interpretation, the observed correlation does not reflect a causal effect from high debt on spending. ADJ (p. 99-100) refer to this mechanism as the "spending-normalization hypothesis." Thus, according to this hypothesis, some households decided to temporarily boost their spending

\footnotetext{
${ }^{1}$ See Svensson $(2019,2020)$ for examples from the international organizations.
} 
to high levels relative to their income before the crisis. Financed by borrowing, the high spending level pushed up pre-crisis debt-to-income ratios for these households. But since the spending boost was only temporary, spending subsequently dropped more for these households than for others, thus generating a negative correlation between pre-crisis indebtedness and spending growth during the crisis.

In examining the Danish microdata, ADJ first find a strong negative correlation between pre-crisis indebtedness of households and the change in spending during the crisis. Then they show that this reflects that highly indebted households spent a larger share of their income than their less-indebted peers prior to the crisis. During the crisis the spending share of their income fell back to a normal level. This is consistent with these households having borrowed in order to finance overspending relative to income pre-crisis, resulting in larger increases in debt for these households in these years. This borrowing and the overconsumption ceased during the crisis, and spending fell back to a normal level. In particular, once ADJ condition on the size of the pre-crisis change in debt, a high level of debt is no longer associated with a larger spending decline. Thus, they reject the debt-overhang hypothesis for Denmark and find support for their spending-normalization hypothesis.

A possible explanations to such a temporary increase in spending pre-crisis is a credit supply shocks, for example, through lower lending standards (Mian and Sufi, 2018). Suppose that some households used easy access to credit before the crisis to borrow large amounts for spending purposes, thus elevating their spending very much relative to their income. If these households were no longer able to borrow because of tighter credit restrictions after the crisis broke out, they would then have to reduce spending, prompting a large decline relative to the pre-crisis level. An alternative explanation centers on expectations for future income (Kaplan, Mitman, and Violante, 2019): Suppose some households had unusually optimistic expectations about future income growth. According to the life-cycle model, those households would have spent a higher fraction of their income than less optimistic households. But the fact that these households were unusually optimistic before the crisis may also imply that they lowered their expectations about future income more than others once the crisis hit, prompting a larger cut in spending. Another alternative explanation mentioned by ADJ is that the indebtedness-spending correlation is related to the timing of purchases of large durable consumption goods, such as cars: Households that happened to buy a car in 2007 most likely saw a large upwards spike in spending in that year. If most of them realistically did not buy a car again within the next two years, the spike in spending was then followed by a large subsequent drop. If financed by borrowing, the car purchase would at the same time have implied a significant increase in debt in 2007 for these households. Under these circumstances, perhaps even random differences in the timing of purchase of large durables can potentially explain the observed correlation between pre-crisis 
leverage and weak subsequent spending growth. ${ }^{2}$

As an additional possible explanation, Svensson (2019, 2020) emphasizes debt-financed overspending through what Muellbauer (2012) calls the "housing-collateral consumption demand channel" and Mian and Sufi (2018) call the "credit-driven household demand channel." Through this channel, housing prices - or, more precisely, changes in housing prices - can affect household consumption. As housing prices rose before the crisis, many households increased their mortgages through housing-equity withdrawal (HEW) in order to finance overspending relative to their income. This showed up in a lower household saving rate. When the crisis hit and housing prices stopped rising and began to fall, further HEW was no longer possible. When the overspending ceased, spending fell back to a more normal level in relation to income and the saving rate rose. The housing-collateral channel-with HEW used for consumption - was not only operating in Denmark, Australia, and the UK before and during the crisis, but also in the US. ${ }^{3} 4$

The ADJ results thus reject the debt-overhang hypothesis for Denmark and support the spending-normalization/debt-financed overspending hypothesis. A most relevant question is whether or not the ADJ results hold for other countries.

In a companion paper to the present one, Svensson (2021) shows that the ADJ results hold also for Australian microdata, so the debt-overhang hypothesis is rejected also for these Australian data and the spending-normalization/debt-financed overspending hypothesis is supported. ${ }^{5}$

\footnotetext{
${ }^{2}$ ADJ (p. 113) separately examine whether the observed borrowing and spending pattern can be entirely explained by car purchases. They find that the share of households with large debt increases that purchased a new car in 2007 was much higher than for other households, but it was still only about 15 percent. For the remaining 85 percent of these households, something else than car purchases must have been behind the large increase in debt and subsequent drop in spending.

${ }^{3}$ As discussed in Price et al. (2019, appendix B) and La Cava et al. (2016), there are institutional features of the Australian mortgage market in the form of so-called offset or redraw facilites that most borrowers have attached to their mortgages. These make housing equity more liquid than otherwise and provide convenient ways to withdraw housing equity for spending purposes.

${ }^{4}$ As noted by Guren et al. (2019, p. 1): "In the mid-2000s boom and subsequent bust, housing wealth extraction through the mortgage market boosted consumption in the boom and reduced consumption in the bust (e.g., Mian and Sufi, 2011; Mian et al., 2013)."

${ }^{5}$ For Australia, Price, Beckers, and La Cava (2019) provide an extensive and thorough exploration of the relationship between owner-occupier mortgage debt and the level of spending in Australia, using detailed HILDA panel microdata on households. They focus on the level of spending in a give year, not on the fall in spending during the crisis years. In particular, they examine whether high levels of household debt causes a weaker levels of spending, what they call a "debt-overhang effect" - to be distinguished from what is here called the debt-overhang hypothesis, which refers to the effect of high debt levels on the fall in spending during the crisis years, as in Mian and Sufi (2010) and Dynan (2012) for the US, ADJ for Denmark, Bunn and Rostom (2014, 2015) for the UK, and Svensson (2021) for Australia. Price et al. (2019) do indeed find evidence of a debt-overhang effect. They furthermore conclude that this debt-overhang effect is not driven by the spending-normalization hypothesis of ADJ. However, they do not test this hypothesis by running exactly the same regressions as ADJ have done. Running the same regressions as ADJ, Svensson (2021) shows that the ADJ results also hold for the HILDA microdata, that the debt-overhang hypothesis is rejected, and that
} 
Regarding the UK, Bunn and Rostom $(2014,2015)$ have been frequently cited in support of the debt-overhang hypothesis for the UK. ${ }^{6}$ In Svensson (2019, pp. 34-38), I scrutinized the results of Bunn and Rostom (2015) (BR) and compared them to those of ADJ. I concluded that, although BR establish the correlation between pre-crisis household indebtedness and consumption cuts during the crisis, they did not explicitly claim causality. Given other evidence of HEW-financed overconsumption and similarities between the Danish and UK data, I concluded that the BR results did not contradict those of ADJ and that the data were actually fully consistent with the spending-normalization/debt-financed overspending hypothesis. However, results of the crucial regressions with changes in household indebtedness added as regressors were not published.

The present paper tests the debt-overhang and spending-normalization/debt-finance hypothesis for the UK by including the missing regressions, on the same microdata as those that BR used. Indeed, the debt-overhang hypothesis is rejected for this data and the spendingnormalization/debt-financed overspending hypothesis is supported.

A very simple model of debt-financed overconsumption - with a home-owning hand-tomouth household facing a loan-to-value (LTV) constraint-shows that consumption and debt changes are directly and strongly positively correlated, whereas consumption and debt levels are quite weakly negatively correlated. Furthermore, at tests of the debtoverhang and spending-normalization/debt-financed overconsumption hypotheses any normalization/scaling should divide consumption cuts, debt levels, and debt changes by the same variable. Importantly, simple examples show that there need not be any systematic relation between consumption cuts and levels of or changes in housing prices and LTV ratios. This is because housing-price falls that lead to violated LTV constraints normally do not require mortgagors to reduce their mortgages. There are no margin calls for mortgagors. The lack of a robust relation between consumption cuts and levels of or changes in LTV ratios implies that tests of these hypotheses should not be done by regressions of consumption cuts on levels of LTV ratios - as in Dynan (2012) and some regressions in Bunn and Rostom (2015) - or changes in LTV ratios.

The paper is outlined as follows. Section 2 presents the simplest possible model of debt-financed overconsumption. Section 3 reports the relevant ADJ results for the Danish microdata. Section 4 presents the results for UK the microdata. Section 5 presents some conclusions.

the spending-normalization/debt-financed overspending hypothesis is supported.

Kearns, Major, and Norman (2020) provide a both broad and detailed analysis of the riskiness of Australian household debt, including stress tests of banks and households. One of their results is that "the household DTI ratio is a poor measure of the extent of risk [posed by Australian household debt]."

${ }^{6}$ An early version of Bunn and Rostom (2015) was published as Bunn and Rostom (2014). 


\section{The simplest model of debt-financed overconsump- tion through the housing-collateral channel}

In order to set up the simplest model of debt-financed overconsumption through the housingcollateral channel, consider a credit- and liquidity-constrained household with owner-occupied housing. Let it be a (wealthy) hand-to-mouth (HTM) household (Campbell and Mankiw, 1989; Kaplan, Violante, and Weidner, 2014; La Cava, Hughson, and Kaplan, 2016) with the the simple budget constraint

$$
C_{t}=\mathrm{EI}_{t}-i_{t} D_{t-1}+\Delta D_{t}
$$

where $C_{t}$ denotes nominal (non-housing) consumption (spending) during year $t, \mathrm{EI}_{t}$ denotes the household's (after-tax) earned income, $D_{t}$ denotes nominal mortgage debt held at the end of year $t, i_{t}$ denotes the (after-tax) nominal interest rate paid in year $t$ on nominal debt held at the end of year $t-1$, and $\Delta D_{t} \equiv D_{t}-D_{t-1}$ denotes the annual change in debt. The household does not receive any transfers, owns no assets except its housing, and has no liabilities except its mortgage debt. For simplicity, there is no operation and maintenance cost of housing, and thus no depreciation of the housing. ${ }^{7}$

The right-hand side of (2.1) is a measure of the household's cash-flow surplus available for consumption and saving, that is, earned income minus interest payments plus the debt increase. An HTM household uses all the available cash-flow surplus for (non-housing) consumption and does not save anything in cash or other liquid assets. The implicit assumption is that the household is credit- and liquidity-constrained to consume less than it would prefer. Its rate of time preference is higher than the interest rate, so the household would prefer to increase its current consumption by borrowing more, if it could.

By (2.1),

$$
\frac{\partial C_{t}}{\partial \Delta D_{t}}=1 \text { and } \frac{\partial C_{t}}{\partial D_{t-1}}=-i_{t}
$$

The marginal propensity to consume (MPC) out of a higher debt increase is positive and unity, whereas the MPC out of a higher (lagged) debt level is small and negative, because the interest rate is much smaller than unity. For an interest rate of $4 \%$, the magnitude of the MPC out of a higher debt increase is 25 times the magnitude of the MPC out of a higher debt level. ${ }^{8}$

\footnotetext{
7 The simple model is extended to include mandatory amortization in (Svensson, 2021, appendix A).

8 We can also see that $\partial C_{t} / \partial i_{t}=-D_{t-1}$. The consumption of highly-indebted HTM households is very sensitive to the interest rate. This is the cash-flow channel of monetary policy (La Cava et al., 2016; Flodén et al., 2018). It implies that highly indebted households with variable interest rates benefit from lower interest rates in crises. With flexible exchange rates and flexible inflation targeting, interest rates become low in recessions. Thus, high debt and variable interest rates provide indebted households with some insurance against bad times (Svensson, 2020, section 3.2).
} 
Clearly, here variations in debt changes will have a much larger effect on fluctuations in current consumption than differences in the lagged debt level.

Assume that the household is subject to a loan-to-value constraint, if it wants to increase its debt,

$$
D_{t} \leq \alpha P_{t} \text { if } \Delta D_{t}>0
$$

Here $\alpha$ denotes the LTV cap (for example, 85\%) and $P_{t}$ denotes the nominal price of the household's housing in year $t$. Restricting the LTV constraint to apply only when debt is increased implies the realistic property of LTV constraints that the household does not have to reduce its debt if housing prices fall and cause the LTV constraint to be violated. (There are no margin calls for mortgage debt.)

Because the household is constrained to consume less than it would prefer, it takes out the maximum possible mortgage - maximizes HEW - each year. If the LTV constraint is not violated at an unchanged debt level, the household will borrow to make or keep the LTV constraint binding. If housing prices have fallen so as to cause the LTV constraint to be violated, the household will keep the debt level constant,

$$
D_{t}= \begin{cases}\alpha P_{t} & \text { if } D_{t-1} \leq \alpha P_{t} \\ D_{t-1} & \text { if } D_{t-1}>\alpha P_{t}\end{cases}
$$

Suppose prices are - and have been - non-decreasing, $\Delta P_{t} \geq 0$, so the the household will keep the LTV constraint (2.3) binding, $D_{t}=\alpha P_{t}$. It then follows from (2.1) that

$$
C_{t}=\mathrm{EI}_{t}-\alpha i_{t} P_{t-1}+\alpha \Delta P_{t} \text { if } \Delta P_{t-1} \geq 0 \text { and } \Delta P_{t} \geq 0
$$

Consumption will be very sensitive to changes in housing prices (as long as housing prices are nondecreasing). This is an example of the housing-collateral household-demand channel with a binding LTV constraint. Thus, the housing-collateral channel is a channel through which housing prices affect consumption. ${ }^{9}$

The household's disposable income equals earned income plus capital income (which is negative here) plus imputed rental income from ownership of the housing. ${ }^{10}$ Introduce DIX $_{t}$, disposable income excluding imputed rental income, which then equals earned income plus capital income,

$$
\operatorname{DIX}_{t} \equiv \mathrm{EI}_{t}-i_{t} D_{t-1}
$$

\footnotetext{
${ }^{9}$ See Muellbauer (2012), Mian and Sufi (2018), and Svensson (2019, 2020) for further discussion of the housing-collateral/credit-driven household demand channel.

10 The imputed rental income from owner-occupied housing in year $t$ in theory equals the user cost of housing in year $t$. In the absence of any operation and maintenance cost and under the simplifying assumption that the cost of housing equity equals the mortgage interest rate, the user cost equals $\left[i_{t+1} P_{t}-(1-\tau) \Delta P_{t+1}\right] /\left(1+i_{t+1}\right)$, where $\tau$ is the (nominal) capital-gains tax on housing.
} 
Then the budget constraint can be written

$$
C_{t}=\mathrm{DIX}_{t}+\Delta D_{t}
$$

(Non-housing) consumption (spending) will equal DIX plus the change in debt.

Figure 2.1: Housing prices, debt, LTV ratios, and consumption

a. Housing prices start to grow at $4 \%$ from year 1 but stay constant from year 10
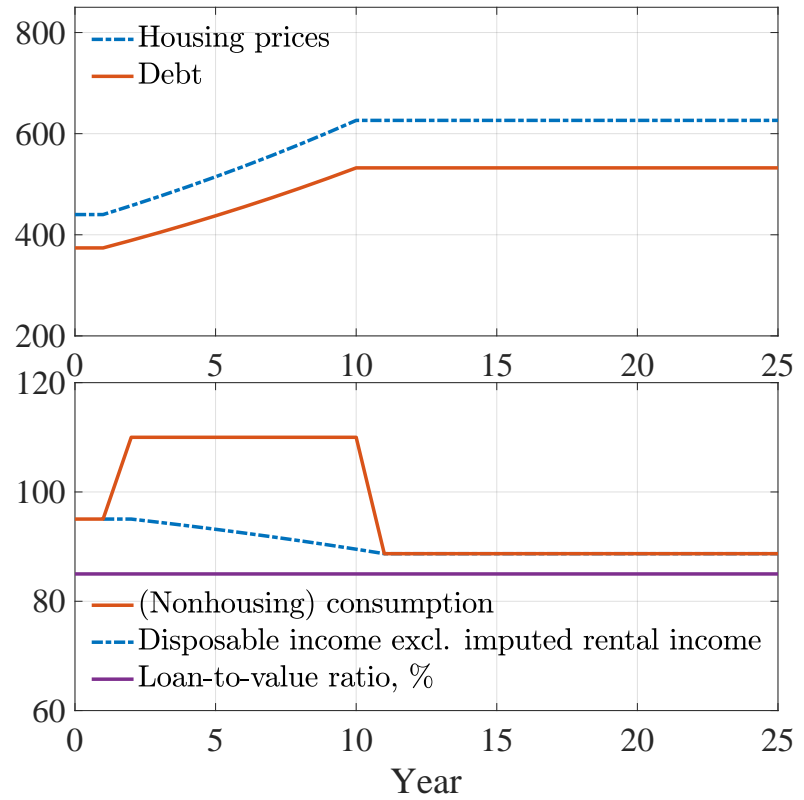

b. Housing prices start to grow at $4 \%$ from year 1 , except for a drop by $25 \%$ in year 11
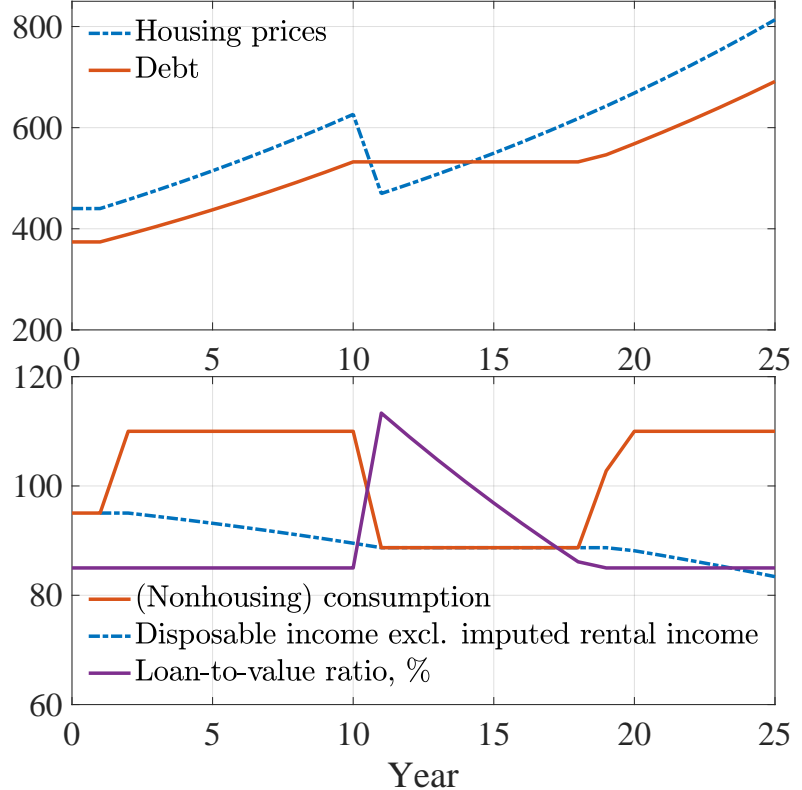

Figure 2.1a shows an example in which earned income is constant and set at $110 .{ }^{11}$ After having been constant at 440, housing prices start to grow at $4 \%$ per year after year 1 but stop growing and stay constant from year 10 onward. The rising housing prices allow the household to increase its mortgage through HEW while maintaining the LTV ratio at the cap of $85 \%$. Thereby it can increase its consumption substantially above DIX from year 2 . DIX is less than earned income by the interest payments. When debt rises, DIX falls further below earned income.

When prices stop growing, the household can no longer increase its mortgage and the debt-financed overconsumption relative to DIX has to stop. Consumption drops by $19 \%$ in year 11 and thereafter remains constant to just equal DIX, the earned income less interest on the debt. Because debt and thereby interest payments are higher in year 11 than in years 1 and 2, consumption and DIX from year 11 onward is lower than in years 1 and 2. This reflects that $\partial C_{t} / D_{t-1}=-i_{t-1}=-0.04$. But it is larger interest payments, not debt in

\footnotetext{
11 The parameters and initial values are $\alpha=85 \%, P_{0}=P_{1}=440$, and $D_{0}=\alpha P_{0}=374$, and $\mathrm{EI}_{t}=\mathrm{EI}=$ 110 and $i_{t}=i=4 \%$ for $t \geq 0$.
} 
itself, that keeps consumption and DIX lower from year 11. A lower mortgage rate in year 11 due to a lower monetary policy rate would increase DIX and consumption and reduce the consumption drop.

Figure 2.1b shows another example, in which housing prices also start to grow at $4 \%$ after year 1 but do not remain constant from year 10 onward. Instead they drop by $25 \%$ in year 11 and then resume to grow at 4\%. The drop in housing prices increases the LTV ratio from the LTV cap of $85 \%$ to $113 \%$. This prevents further HEW, and consumption drops by $19 \%$. The rising housing prices reduce the LTV ratio back toward the LTV cap and in year 19 the household resumes HEW and debt-financed overconsumption relative to DIX.

In figures 2.1a and b, we can interpret year 11 as a crisis year and year 10 as a pre-crisis year. The consumption change from year 10 to year 11 is in these examples by (2.1) given by

$$
C_{11}-C_{10}=\Delta C_{11}=\Delta \mathrm{EI}_{11}-i \Delta D_{10}+\left(\Delta D_{11}-\Delta D_{10}\right)=-i \frac{g}{1+g} D_{10}-\Delta D_{10} .
$$

Here we use that $\mathrm{EI}_{t}=\mathrm{EI}$ and $i_{t}=i$ are constant; that $i \Delta D_{10}=i g D_{9}=i g D_{10} /(1+g)$, where $g$ is the constant growth rate of housing prices and debt up to year 10; and that $\Delta D_{11}=0$, because debt is constant after year 10 for several years.

With $i=4 \%$ and $g=4 \%$, on the right-hand side of (2.8) the coefficient of $D_{10}$ is only minus 0.0015 , whereas the coefficient on $\Delta D_{10}$ is minus 1 . So in these simple examples, the consumption fall during the "crisis" overwhelmingly depends on the pre-crisis debt increase, $\Delta D_{10}$, not on the pre-crisis debt level, $D_{10}$. The pre-crisis debt level has a small increasing effect on the consumption fall due to the interest payments on the pre-crisis debt increase, $i \Delta D_{10}=i g D_{10} /(1+g){ }^{12}$

What causes the consumption fall in these examples? First, the credit- and liquidityconstrained HTM household desires to increase its consumption (its rate of time preference exceeds the after-tax mortgage interest rate). This implies a binding LTV constraint (when housing prices are non-decreasing). Second, a period of rising housing prices eases the LTV constraint and allows debt increases through HEW to finance a welcome overconsumption relative to the households disposable income. Third, an end to the period of rising housing prices prevent further HEW-financed overconsumption, which forces consumption to fall back to equal DIX (disposable income excluding imputed rental income). Thus, given the setup, the fall in consumption is caused by the stop in HEW, which in turn is caused by the end of the period of rising housing prices. The HEW during the period of rising housing prices is caused by the household's desire to increase its consumption.

\footnotetext{
${ }^{12}$ If we do not assume a constant interest rate, the term $i \Delta D_{10}$ is replaced by $i_{11} D_{10}-i_{10} D_{9}=i_{11} \Delta D_{10}+$ $\Delta i_{11} D_{9}$. This illustrates that a fall in the interest rate during the crisis, $\Delta i_{11}<0$, will for a large debt level through the fall in interest payments have a large dampening effect on the consumption fall of the HTM household (the cash-flow channel of monetary policy).
} 
Whereas there is, by the budget constraint (2.1), a direct relation between the change in debt and consumption for an HTM household with an LTV constraint, there is, by the liquidity constraint (2.4), a rather non-linear relation between housing prices and debt, as illustrated by the two examples in the top panels of figure 2.1. As a result, there is little systematic relation between the LTV ratio and the consumption fall in year 11 . In the example in figure 2.1a, the LTV ratio is constant before, during, and after the fall in consumption. In the example in figure $2.1 \mathrm{~b}$, with the same consumption fall in year 11 , there is a rise in the LTV ratio in year 11, completely due to the fall in housing prices. The fall in consumption is furthermore independent of the fall in housing prices. Then, for a few years, consumption remains constant, while the LTV ratio falls towards the LTV cap, again completely due to the rise in housing prices.

Given this, for HTM households with LTV constraints, it makes little sense to regress the crisis consumption fall on levels of and changes in the pre-crisis LTV ratios. The lack of a robust relation between consumption cuts and levels of or changes in LTV ratios implies that tests of the debt-overhang hypothesis should generally not be done by regressions of consumption cuts on levels of LTV ratios - as in Dynan (2012) and some regressions in Bunn and Rostom (2015) - or changes in LTV ratios.

\section{The Andersen et al. (2016a) results for Danish mi- crodata}

ADJ test the debt-overhang and spending-normalization/debt-financed overspending hypotheses on Danish microdata (registry data). The crucial regression is of the form

$$
\frac{C_{2009}^{h}-C_{2007}^{h}}{Y_{2007}^{h}}=\alpha+\delta_{1}\left(\frac{D_{2007}^{h}}{Y_{2007}^{h}}\right)^{\mathrm{High}}+\delta_{2}\left(\frac{D_{2007}^{h}-D_{2006}^{h}}{Y_{2007}^{h}}\right)^{\mathrm{High}}+\lambda \mathbf{X}_{2007}^{h}+\varepsilon^{h},
$$

where $C_{t}^{h}$ denotes (imputed) spending by household $h$ in year $t, Y_{t}^{h}$ denotes pre-tax income in year $t, D_{t}^{h}$ denotes total debt at the end of year $t$, and $\mathbf{X}_{t}^{h}$ is a vector of control variables containing a range of household characteristics as of year $t$. The expression $\left(Z_{t}^{h}\right)^{\text {High }}$ denotes a dummy for $Z_{t}^{h}$ exceeding its 75 th percentile in year $t .{ }^{13}$

We note the similarity of (3.1) to (2.8). We also note that, by (2.8), any normalization by pre-tax income or any other variable in (3.1) should involve dividing the spending change on

\footnotetext{
13 The registered-based data ADJ use do not include consumption or spending at the household level. They instead rely on a spending measure imputed on data from household disposable income, assets, and liabilities. In order to exclude capital gains on housing, they restrict the sample to households that have not bought or sold one or more homes during the sample. The sample still include close to 500,000 households (ADJ, section 3).
} 
the left-hand side and the debt level and change on the right-hand side by the same variable, in this case pre-crisis pre-tax income.

According to the debt-overhang hypothesis, high indebtedness of a household in 2007 caused a larger drop in the household's spending from 2007 to 2009 . A test of the hypothesis is then whether or not the estimate of the coefficient $\delta_{1}$ is negative as well as statistically and economically significant.

According to the spending-normalization/debt-financed overspending hypothesis, a larger fall in spending from 2007 to 2009 is due to overspending in 2007 financed by a high debt increase from 2006 to 2007. The hypothesis then implies that the fall in spending is predicted by a high debt increase rather than by a high debt level in $2007 .{ }^{14}$ A test of the hypothesis is then whether - when the debt increase is included among the explanatory variables - the estimate of the coefficient $\delta_{2}$ is negative as well as economically and statistically significant, together with the estimate of $\delta_{1}$ being small and economically insignificant. Put differently, whether a regression with the debt level as regressor without the change in debt is subject to an omitted-variable problem.

The main result is reported in ADJ (table 4), reproduced here as table 3.1. ${ }^{15}$ The result in column (1) of the table, with the dummy for a high debt level as the only regressor (besides controls), gives some support for the debt-overhang hypothesis. However, in column (3), where the dummy for a high debt change is added as a regressor, the debt-overhang hypothesis is rejected and the spending-normalization/debt-financed overspending hypothesis is supported. The negative correlation between high pre-crisis debt and larger subsequent spending falls is entirely driven by the fact that a large share of the households with high debt-to income ratios in 2007 had increased their debt by large amounts for consumption purposes in the run-up to the crisis. The level of debt itself does not help to explain the larger spending decline for this group. Not including the change in debt among the explanatory variables thus results in a standard omitted-variable bias of the estimate of the coefficient on a high DTI ratio.

Columns (6) and (7) show that the same result occurs when the change in debt from 2003 to 2007 is substituted for the change from 2006 to 2007.

ADJ (p. 108) summarize the main result as,

within groups of households that experienced similar-sized changes in debt from 2006 to 2007, those with a high level of debt in 2007 did not reduce spending

\footnotetext{
14 According to this hypothesis, it is an increase in spending intentions that leads to a debt increase to support consumption. That is, there is reverse causality. Therefore, the debt increase predicts rather than causes the fall in spending.

15 Note that the second regressor in (3.1) refers to the change in debt from 2006 to 2007 divided by income in 200\%, not the change in the debt-to-income ratio from 2006 to 2007, as has been confirmed in correspondence with Asger Andersen. The heading/note to ADJ (table 4) causes some confusion by mistakenly referring to the change in the debt-to-income ratio, but the text of the paper is clear.
} 
Table 3.1: Regressions for Denmark of the change in imputed spending relative to income on high levels of and high changes in mortgage debt relative to income (Andersen, Duus, and Jensen, 2016a, table 4)

Dependent variable: Change in imputed spending from 2007 to 2009 relative to pre-tax income in 2007

\begin{tabular}{|c|c|c|c|c|c|}
\hline \multirow[b]{2}{*}{ Variables } & \multirow[t]{2}{*}{$(1)$} & $(2)$ & $(3)$ & $(6)$ & $(7)$ \\
\hline & & \multicolumn{2}{|c|}{ Change from 2006 to 2007} & \multicolumn{2}{|c|}{ Change from 2003 to 2007} \\
\hline$\left(\frac{D_{2007}^{h}}{Y^{h}}\right)^{\text {High }}$ & $-0.0448^{* * *}$ & & $0.0224^{* * *}$ & & $0.0211^{* * *}$ \\
\hline & $(0.0017)$ & & $(0.0017)$ & & $(0.0019)$ \\
\hline$\left(\frac{D_{2007}^{h}-D_{2006}^{h}}{Y^{h}}\right)^{\text {High }}$ & & $-0.2601^{* * *}$ & $-0.2654^{* * *}$ & & \\
\hline 2006 & & $(0.0016)$ & $(0.0016)$ & & \\
\hline$\left(\frac{D_{2007}^{h}-D_{2003}^{h}}{Y^{h}}\right)^{\text {High }}$ & & & & $-0.1267^{* * *}$ & $-0.1363^{* * *}$ \\
\hline & & & & $(0.0016)$ & $(0.0018)$ \\
\hline Observations & 492,194 & 492,194 & 492,194 & 492,194 & 492,194 \\
\hline R-squared & 0.0488 & 0.0972 & 0.0976 & 0.0592 & 0.0594 \\
\hline
\end{tabular}

Source and note: See ADJ (table 4) for details. Columns are numbered as in ADJ, duplicate column (5) is excluded. A typo in table 4, column (2) is corrected; the crucial minus in front of the coefficient $0.2601^{* * *}$ is inserted. The expression $\left(Z^{h}\right)^{\mathrm{High}}$ denotes a dummy for the variable $Z^{h}$ exceeding its 75 th percentile in 2007. The control variables (coefficients are not reported) include municipality, age of oldest member, number of children, no. of years since moving in, higher education, retirees, decile of income, decile of net wealth to income, and decile of liquid assets to income; all are measured in 2007. Standard errors in parenthesis. *, **, and $* * *$ denotes significance at the $5 \%, 1 \%$, and $0.1 \%$ level, respectively.

more from 2007 to 2009 than those with only little debt in 2007. But those that experienced a large increase in debt from 2006 to 2007 cut spending by more than those that did not experience a large increase, even if they had similar debt levels at the end of 2007... [T] he results are the same if we instead use the change in debt since 2003, rather than 2006.

Broadbent (2019) summarized the ADJ result as: ${ }^{16}$

Once you know the change in a household's indebtedness ahead of the crisis, knowing the level tells you nothing more about its subsequent spending.

In the regressions in table 3.1 the regressors are indicator variables of high debt and high debt change, more precisely, dummies for the debt-to-income ratio and the debt change normalized by income exceeding their 75 th percentile. In an online appendix to ADJ, (Andersen et al., 2016b, table A5, reproduced here as table 3.2), the authors also report a regression of changes in spending on continuous measures of levels and changes in debt, with the same qualitative result.

\footnotetext{
16 Broadbent (2019) provides an insightful discussion and several examples of why the level of household debt - at very different points of time, across countries, and even for individual households - is a poor predictor of subsequent financial distress, and why debt growth does better.
} 
Table 3.2: Regressions for Denmark of the change in spending on continuous measures of levels of and changes in debt (Andersen, Duus, and Jensen, 2016b, table A5)

Dependent variable: Change in imputed spending from 2006 to 2007 , relative to pre-tax income in 2007

\begin{tabular}{lccc}
\hline & $(1)$ & $(2)$ & $(3)$ \\
\hline$\frac{D_{2007}^{h}}{Y_{2007}^{h}}$ & $-0.0145^{* * *}$ & & $0.0322^{* * *}$ \\
$D_{2007}^{h}-D_{2006}^{h}$ & $(0.0006)$ & & $(0.00506)$ \\
$Y_{2007}^{h}$ & & $-0.5696^{* * *}$ & $-\mathbf{0 . 6 0 7 5 * * *}$ \\
& & $(0.0023)$ & $(0.0024)$ \\
Observations & 492,194 & 492,194 & 492,194 \\
R-squared & 0.0485 & 0.1544 & 0.1592 \\
\hline
\end{tabular}

Source and note: See Andersen, Duus, and Jensen (2016b, table A5) for details. Columns are numbered as in ADJ (2016b, table A5). $D_{t}^{h}$ denotes the debt level in year $t$, and $Y_{2007}^{h}$ denotes pre-tax income in year 2007. Control variables include municipality, age of oldest member, number of children, no. of years since moving in, higher education, retirees, decile of income, decile of net wealth to income, and decile of liquid assets to income; all are measured in 2007. Standard errors in parenthesis. ${ }^{*},{ }^{* *}$, and ${ }^{* * *}$ denote significance at the $5 \%, 1 \%$, and $0.1 \%$ level, respectively.

Thus, the ADJ result rejects the debt-overhang hypothesis for Denmark and supports the spending-normalization/debt-financed overspending hypothesis, both for discrete and continuous measures of indebtedness and the change in indebtedness. Svensson (2021) shows that the ADJ results also hold for Australian microdata. An important question is to what extent the ADJ result holds for additional countries, in this case for the UK.

\section{Results on UK microdata}

\subsection{Bunn and Rostom (2015)}

As mentioned, Bunn and Rostom (2015) (BR) document a correlation between pre-crisis household indebtedness and consumption spending cuts during the financial crisis for the UK. They use a synthetic panel of UK microdata - following Deaton (1985) - constructed from the Living Cost and Foods (LCF) Survey (UK Data Service, 2020), using two pooled years and cohorts with of a single birth year and five and ten birth years (see BR for details).

Because the LCF data are a repeated cross-section and not a panel, households in the survey are different in each year. Therefore, BR cannot examine how debt and spending varied over the years across individual households. Instead, they examine how debt and spending varied over the years across different cohorts, where the cohorts comprise different households in each year. Relying on cohort-level analysis is of course a disadvantage, because of life-cycle variations of income, spending, and debt. The results on the relation between debt and spending cuts during the crisis may be driven by the young. This is indeed 
confirmed by Kovacs, Rostom, and Bunn (2018) and is briefly discussed in section 4.2.

$\mathrm{BR}$ estimate a regression of the form

$$
c_{09 / 10}^{h}-c_{06 / 07}^{h}=\beta_{0}+\beta_{1} \mathrm{DTI}_{06 / 07}+\lambda \mathbf{X}_{06 / 07}^{h}+\varepsilon^{h},
$$

where $c_{t}^{h}$ for $t=09 / 10$ and 06/07 denotes the log of non-housing consumption for cohort $h$ in the pooled years 2009/2010 and 2006/2007, respectively, and $\mathrm{DTI}_{06 / 07}^{h}$ denotes the ratio of mortgage debt to post-tax income in 2006/2007. Furthermore, $\mathbf{X}_{06 / 07}^{h}$ is a vector of control variables, namely changes in log income net of mortgage interest, number of adults, number of children, $\log$ housing wealth, and $\log$ financial wealth. ${ }^{17}$

Thus, the dependent variable is the consumption growth rate from 2006/2007 to 2009/2010, regressed on a continuous measure of debt-to-income (DTI) ratios on 2006/2007. Columns (1), (3), and (5) in table 4.1 report the results (for single and five birth years) in columns (1), (3), and (5) in their table 2. The results establish a negative correlation between pre-crisis indebtedness and consumption growth during the crisis. In isolation, they seem to give some support for the debt-overhang hypothesis.

Table 4.1: Regressions for the UK of consumption growth on the level of and change in mortgage debt-to-income ratios

Dependent variable: Change in log non-housing consumption from 2006/2007 to 2009/2010)

\begin{tabular}{|c|c|c|c|c|c|c|}
\hline Cohort definition & \multicolumn{2}{|c|}{ Single birth year } & \multicolumn{2}{|c|}{$\begin{array}{c}\text { Single birth year } \\
\text { mortgagor/non-mortgagor }\end{array}$} & \multicolumn{2}{|c|}{$\begin{array}{c}\text { Five birth year } \\
\text { mortgagor/non-mortgagor }\end{array}$} \\
\hline Variables & (1) & $(2)$ & (3) & (4) & (5) & (6) \\
\hline $\mathrm{DTI}_{06 / 07}$ & $\begin{array}{c}-0.030^{* *} \\
(0.014)\end{array}$ & $\begin{array}{l}-0.002 \\
(0.017)\end{array}$ & $\begin{array}{c}-0.028^{* * *} \\
(0.007)\end{array}$ & $\begin{array}{l}-0.009 \\
(0.009)\end{array}$ & $\begin{array}{c}-0.026^{* *} \\
(0.009)\end{array}$ & $\begin{array}{c}0.005 \\
(0.011)\end{array}$ \\
\hline$\Delta \mathrm{DTI}_{03 / 04-06 / 07}$ & & $\begin{array}{c}-\mathbf{0 . 0 4 1 *} \\
(0.024)\end{array}$ & & $\begin{array}{c}-\mathbf{0 . 0 9 8 *} \\
(0.053)\end{array}$ & & $\begin{array}{c}-\mathbf{0 . 2 2 2} * * * \\
(0.053)\end{array}$ \\
\hline Observations & 45 & 42 & 76 & 70 & 19 & 18 \\
\hline R-squared & 0.726 & 0.687 & 0.570 & 0.602 & 0.818 & 0.914 \\
\hline
\end{tabular}

Source and note: Bunn and Rostom (2015, table 2, columns (1), (3), and (5); reproduced and numbered in the same way here), and additional regressions provided by the authors on the same data (columns (2), (4), and (6)). In this table, $\Delta \mathrm{DTI}_{03 / 04-06 / 07} \equiv \mathrm{DTI}_{06 / 07}-\mathrm{DTI}_{03 / 04}$ denotes the change in the debt-to-income ratio from 2003/2004 to 2006/2007. Control variables include changes in log income net of mortgage interest, number of adults, number of children, $\log$ housing wealth, and $\log$ financial wealth. The regressions are done on a synthetic panel - following Deaton (1985) - constructed using two pooled years and cohorts with of a single birth year and five birth years. Cohorts are also split into mortgagors and non-mortgagors. See Bunn and Rostom $(2015)$ for details. OLS. Robust standard errors in parentheses. ${ }^{*}, * *$, and ${ }^{* * *}$ denote significance at the $10 \%, 5 \%$, and $1 \%$ level, respectively.

But table 2 of $\mathrm{BR}$ does not include any measure of pre-crisis changes in debt among the regressors. Columns (2), (4), and (6) in table 4.1 show that, when the regression is amended to include changes in the DTI ratio from 2003/2004 to 2006/2007, the results

\footnotetext{
17 The control variables thus differ between the BR and ADJ regressions, including that ADJ use levels and BR changes.
} 
are qualitatively similar to the ADJ results in table 3.2. In particular, the debt-overhang hypothesis is rejected, and the regression on only the DTI ratio is subject to omitted-variable bias.

However, the regression equation in table 4.1 is not exactly the same regression as the continuous version of (3.1) in ADJ, underlying table 3.2. As suggested by the simple model of debt-financed overconsumption, the left-hand and right-hand side of (2.8) should be normalized by the same variable - in the ADJ case the income in 2007. However, in table 4.1, the dependent variable - the left-hand side of $(4.1)$ - is approximately $\left(C_{09 / 10}^{h}-C_{06 / 07}^{h}\right) / C_{06 / 07}^{h}$, that is, the change in consumption normalized by consumption in 2006/2007 rather than by income. On the right-hand side, the added regressor is the change in the DTI ratio, $D_{06 / 07}^{h} / Y_{06 / 07}^{h}-D_{03 / 04}^{h} / Y_{03 / 04}^{h}$, not the change in debt normalized by income in 2006/2007, $\left(D_{06 / 07}^{h}-D_{03 / 04}^{h}\right) / Y_{06 / 07}^{h}$. For these reasons - although the results are sufficient to reject the debt-overhang hypothesis - the amended regressions here do not represent as appropriate a test of the spending-normalization/debt-financed overconsumption hypothesis as the ADJ regressions. ${ }^{18}$ Nevertheless, the results in table 4.1 provide some support for this hypothesis.

BR (table 2, columns (2), (4), and (6); not reported here) also provide regressions of (4.1) where the DTI ratio is replaced by the loan-to-value (LTV) ratio. Relative to (2.8), this implies a rather arbitrary normalizing of the left-hand side by consumption in 2006/2007 and of the right-hand side by the housing price in 2006/2007. But, as noted in the discussion at the end of section 2, for the simple model of an HTM household with an LTV constraint, there is no systematic relation between the LTV ratio and a fall in consumption. For the experiment shown in figure 2.1a, the LTV ratio is constant before, during, and after the large fall in consumption in year 11, the "crisis". In the experiment in figure $2.1 \mathrm{~b}$, there is a simultaneous fall in consumption and rise in the LTV ratio (the latter completely due to the fall in housing prices). But the fall in consumption is independent of the magnitude of rise in the LTV ratio. The lack of a robust relation between consumption cuts and levels of or changes in LTV ratios implies that tests of the debt-overhang hypothesis should generally not be done by regressions of consumption cuts on levels of or changes in LTV ratios.

In summary, the debt-overhang hypothesis is rejected also for the regressions in table 4.1 for these microdata for the UK, and the spending-normalization/debt-finance-overspending hypothesis receives some support.

\subsection{Kovacs, Rostom, and Bunn (2018)}

Kovacs et al. (2018, table 2) (KRB), reproduced here as table 4.2, report regression results similar to those in BR (table 2, column (3)), except that the sample is split by whether the

\footnotetext{
18 The change in the DTI ratio is obviously affected by the change in income.
} 
household head is younger or older than 40 years (denoted "young" and "old", respectively). They make the point that the results are mainly driven by the young. The regression result for the young is similar to the result in column (3), but the negative coefficient on the DTI ratio is larger in magnitude. In the regression for the old, the coefficient is smaller and only significant at a 10 percent level.

Table 4.2: Regressions by age for the UK of consumption growth on the level of and change in mortgage debt-to-income ratios (Kovacs, Rostom, and Bunn, 2018, table 2)

Dependent variable: Change in log non-housing consumption from $2006 / 2007$ to $2009 / 2010$

\begin{tabular}{lcc}
\hline Sample split: & Young & Old \\
Variables & $(1)$ & $(2)$ \\
\hline $\mathrm{DTI}_{06 / 07}$ & $-0.035^{* * *}$ & $-0.020^{*}$ \\
& $(0.010)$ & $(0.010)$ \\
Observations & 26 & 51 \\
\hline
\end{tabular}

Source and note: Kovacs et al. (2018, table 2). Coefficients of the change in after-tax income, change in housing wealth and financial wealth are not reported. Controls are the change in the number of adults and children. Sample is split by whether the household head is younger than 40 years or otherwise. Robust standard errors in parentheses. ${ }^{*},{ }^{*}$, and ${ }^{* * *}$ denote significance at the $10 \%, 5 \%$, and $1 \%$ level, respectively.

KRB do not include the change in the DTI ratios among the regressors. But given the results in column (3) and (4) in table 4.1, it is pretty clear that, if the change in DTI ratios were to be included, the results for the young would be qualitatively similar to those in column (4) in table 4.1. The debt-overhang hypothesis would be rejected, and the spendingnormalization/debt-financed overconsumption hypothesis would receive some support. The KBR regressions are subject to the same omitted-variable problem as the BR ones.

\section{Conclusion}

The results presented here for UK microdata reject the "debt-overhang hypothesis" — that households cut back more on their spending in a crisis when they have higher levels of outstanding mortgage debt (Dynan, 2012). The results instead provide some support for the "spending-normalization hypothesis" of Andersen, Duus, and Jensen (2016a), what can also be called the "debt-financed overspending" hypothesis - that the correlation between high pre-crisis household indebtedness and subsequent spending falls during the crisis reflected high debt-financed spending pre-crisis and a return to normal spending during the crisis. As further discussed in Svensson (2019, 2020), this is consistent with the correlation reflecting debt-financed overspending through what Muellbauer (2012) calls the "housing-collateral household-demand" and Mian and Sufi (2018) the "credit-driven household demand" channel.

It follows that it was not high household indebtedness in itself that caused the fall in 
spending during the crisis in Denmark, Australia, and the UK. ${ }^{19}$ There were some highly indebted households that cut down their spending more than others did, but this is better explained by these households having before the crisis engaged in a mortgage-financed overspending relative to income. This overspending could not continue during the crisis, and spending fell.

At the same time, increased mortgage loans for consumption purposes contributed to many households being highly indebted. Mortgage financing of overspending thus caused both the fall in spending and to a certain extent the high indebtedness. This created a correlation between high indebtedness and subsequent consumption declines - but not a causal relationship between them.

It follows that high household debt-to-income ratios in themselves contain little or no information about risks of a spending fall associated with household indebtedness. This is in contrast to what seems to be taken for granted by macroprudential authorities in many countries, as well as by the international organizations that comment on countries' macroprudential policy. As discussed in Svensson $(2019,2020)$, in order to assess such risks of a spending fall, among other things, one needs to examine whether there is any evidence of an active housing-collateral channel and any mortgage-financed overspending of macroeconomic significance - an aggregate debt-financed consumption boom, for example resulting in a low household saving rate. ${ }^{20}$ As Muellbauer (2012) emphasizes, the strength of the housing-collateral channel varies considerably between countries depending on differences in the structure of housing and mortgage markets as well as in customs and preferences. Furthermore, if there is significant housing-equity withdrawal, it matters for the risk assessment whether this is used for consumption purposes - whether mortgages are effectively used as consumption loans - or for other purposes, such as home improvement, paying off expensive consumer loans, or investment in financial assets, including keeping a liquidity buffer.

These issues for Sweden and their relevance for Swedish macroprudential policy — and for the recommendations of the relevant international organizations - are further discussed in Svensson $(2019,2020)$.

It remains to test these hypothesis for other countries than Denmark, Australia, and the UK. I would not be surprised if the rejection of the debt-overhang hypothesis and support for the debt-financed overconsumption hypothesis is a pretty general result.

\footnotetext{
19 See also Broadbent (2019) and Kearns et al. (2020).

20 Cf. the role of consumption booms in Mian, Sufi, and Verner (2017).
} 


\section{References}

Andersen, Asger Lau, Charlotte Duus, and Thais Lærkholm Jensen (2016a), "Household Debt and Spending During the Financial Crisis: Evidence from Danish Micro Data," European Economic Review 89, 96-115, https://doi.org/10.1016/j.euroecorev.2016.06.006.

Andersen, Asger Lau, Charlotte Duus, and Thais Lærkholm Jensen (2016b), "Household Debt and Spending During the Financial Crisis: Evidence from Danish Micro Data: Online Apendix," European Economic Review 89, 96-115, https://doi.org/10.1016/ j.euroecorev.2016.06.006.

Broadbent, Ben (2019), "Debt Dynamics," speech at London Business School, January 23, 2019, Bank of England, https://www.bankofengland.co.uk/speech/2019/ben-broadbentspeech-at-london-business-school.

Bunn, Philip, and May Rostom (2014), "Household Debt and Spending," Bank of England Quarterly Bulletin 2014 Q3 54(3), 304-315, https://www.bankofengland.co.uk/quarterlybulletin/2014/q3/household-debt-and-spending.

Bunn, Philip, and May Rostom (2015), "Household Debt and Spending in the United Kingdom," Staff Working Paper No. 554, Bank of England, https://www.bankofengland.co.uk/ working-paper/2015/household-debt-and-spending-in-the-uk.

Campbell, John Y., and N. Gregory Mankiw (1989), "Consumption, Income, and Interest Rates: Reinterpreting the Time Series Evidence," NBER Macroeconomics Annual 1989, 185-216, https://www.nber.org/chapters/c10965.pdf.

Carney, Mark (2020), "The Grand Unifying Theory (and Practice) of Macroprudential Policy," Speech at University College, London, on March 5, 2020, Bank of England, https://www.bankofengland.co.uk/speech/2020/mark-carney-speech-at-universitycollege-london.

Deaton, Angus (1985), "Panel Data from Time Series of Cross-sections," Journal of Econometrics 30(1), 109-126, https://doi.org/10.1016/0304-4076(85)90134-4.

Dynan, Karen (2012), "Is Household Debt Overhang Holding Back Consumption?" Brookings Papers on Economic Activity Spring 2012, 299-344, https://www.brookings.edu/wpcontent/uploads/2016/06/2012a_Dynan.pdf.

Finansinspektionen (2017), "A Stricter Amortization Requirement for Households with High Loan-to-Income Ratios," Decision Memo FFFS 2017:23, Ref. 17-9236, December 11, 2017, Finansinspektionen-The Swedish Financial Supervisory Authority, https://www.fi.se/ en/our-registers/search-fffs/2016/201616/201723/.

Flodén, Martin, Matilda Kilström, Jósef Sigurdsson, and Roine Vestman (2018), "Household Debt and Monetary Policy: Revealing the Cash-Flow Channel," working paper, http: //www.matildakilstrom.com/wp-content/uploads/2016/01/FKSV_20180802.pdf. 
Guren, Adam M., Arvind Krishnamurthy, and Timothy J. McQuade (2019), "Mortgage Design in an Equilibrium Model of the Housing Market," working paper, http: //people.bu.edu/guren/gkm_mortgage_design.pdf.

Kaplan, Greg, Kurt Mitman, and Giovanni L. Violante (2019), "The Housing Boom and Bust: Model Meets Evidence," Journal of Political Economy, forthcoming, https://static1.squarespace.com/static/5d69437d65a29d0001ae6520/t/ 5daa58e5a6cdd33e2a9060e4/1571444967065/kaplan_mitman_violante_sep2019.pdf.

Kaplan, Greg, Giovanni L. Violante, and Justin Weidner (2014), "The Wealthy Handto-Mouth," Brookings Papers on Economic Activity Spring 2014, 77-138, https:// www.brookings.edu/wp-content/uploads/2016/07/2014a_Kaplan.pdf.

Kearns, Jonathan, Mike Major, and David Norman (2020), "How Risky is Australian Household Debt?" Research Discussion Paper RDP 2020-05, Reserve Bank of Australia, https://www.rba.gov.au/publications/rdp/2020/2020-05.html.

Kovacs, Agnes, May Rostom, and Philip Bunn (2018), "Consumption Response to Aggregate Schocks and the Role of Leverage," Discussion Paper No CFM-DP2018-20, Centre for Macroeconomics, http://www.centreformacroeconomics.ac.uk/Discussion-Papers/ 2018/CFMDP2018-20-Paper.pdf.

La Cava, Gianni, Helen Hughson, and Greg Kaplan (2016), "The Household Cash Flow Channel of Monetary Policy," Research Discussion Paper RDP 2016-12, Reserve Bank of Australia, https://www.rba.gov.au/publications/rdp/2016/2016-12.html.

Mian, Atif, Kamalesh Rao, and Amir Sufi (2013), "Household Balance Sheets, Consumption, and the Economic Slump," Quarterly Journal of Economics 128(4), 1687-1726.

Mian, Atif, and Amir Sufi (2010), "Household Leverage and the Recession of 2007-2009," IMF Economic Review 58(1), 74-117.

Mian, Atif, and Amir Sufi (2011), "House Prices, Home Equity-Based Borrowing, and the US Household Leverage Crisis," American Economic Review 101(5), 2132-2156.

Mian, Atif, and Amir Sufi (2018), "Finance and Business Cycles: The Credit-Driven Household Demand Channel," Journal of Economic Perspectives 32(3), 31-58.

Mian, Atif, Amir Sufi, and Emil Verner (2017), "Household Debt and Business Cycles Worldwide," Quarterly Journal of Economics 132(4), 1755-1817.

Muellbauer, John (2012), "When Is a Housing Market Overheated Enough to Threaten Stability," in Heath, Alexandra, Franck Packer, and Callan Windsor (eds.), Property Markets and Financial Stability, Reserve Bank of Australia, pages 73-105, https: //www.rba.gov.au/publications/confs/2012/pdf/conf-vol-2012.pdf.

Price, Fiona, Benjamin Beckers, and Gianni La Cava (2019), "The Effect of Mortgage Debt on Consumer Spending: Evidence from Household-level Data," Research Discussion Paper RDP 2019-06, Reserve Bank of Australia, https://www.rba.gov.au/publications/rdp/ 2019/pdf/rdp2019-06.pdf. 
Svensson, Lars E.O. (2019), "Housing Prices, Household Debt, and Macroeconomic Risk: Problems of Macroeconomic Policy I," working paper, Stockholm School of Economics, https://larseosvensson.se/2018/12/16/housing-prices-household-debt-andmacroeconomic-risk-problems-of-macroprudential-policy-i/.

Svensson, Lars E.O. (2020), "Macroprudential Policy and Household Debt: What is Wrong with Swedish Macroprudential Policy?" Nordic Economic Policy Review 2020, 111167, https://larseosvensson.se/2019/12/05/macroprudential-policy-and-household-debtwhat-is-wrong-with-swedish-macroprudential-policy/.

Svensson, Lars E.O. (2021), "High Household Debt-to-Income Ratios Did Hardly Cause a Larger Spending Fall During the Financial Crisis in Australia," working paper, Stockholm School of Economics, https://larseosvensson.se/2021/04/12/household-debt-overhangdid-hardly-cause-a-larger-spending-fall-during-the-financial-crisis-in-australia/.

UK Data Service (2020), "Key Data," website, UK Data Service, https:// www.ukdataservice.ac.uk/get-data/key-data/uk-survey-series.aspx. 